\title{
KAJIAN WARNA DAN CORAK BULU PADA BURUNG WERIS DI KOTA KOTAMOBAGU SULAWESI UTARA
}

\author{
Bayu A. Sinyo*, L. Lambey** F. Kairupan;** J. Keintjem**) \\ Fakultas Peternakan Universitas Sam Ratulangi Manado, 95115
}

\begin{abstract}
ABSTRAK
Burung mandar (Gallirallus) yang dalam bahasa lokal dikenal dengan nama Weris (Minahasa), dan Boruit (Kotamobagu) merupakan burung yang masuk dalam keluarga Rallidae, yaitu keluarga burung yang memiliki ukuran tubuh kecil hingga menengah. Habitat umum dari jenis burung ini adalah rawa, dekat sungai atau danau. Burung weris umumnya berkembang biak di daerah yang bervegetasi padat Menurut Rusila (1994) . Identifikasi maslah dalam penelitian adalah warna indentifikasi dan corak bulu, dua spesis burung weris yang ada di Kotamobagu (Sulawesi Utara). Tujuan penelitian ini adalah untuk mendapatkan data mengenai ragam warna dan corak burung weris yang ada di Kotamobagu, Kab. Bolaang mongondow, Sulawesi Utara. Manfaat yang diharapkan dalam penelitian ini yaitu dapat memberikan informasi mengenai identifikasi warna dan corak bulu burung weris, berguna proses penangkaran.

Burung weris yang ada di Indonesia terdiri dari beberapa jenis, berdasarkan hasil penelitian yang dilakukan di Kotamobagu Kabupaten Bolaang Mongondow Sulawesi Utara didapatkan 2 jenis burung weris yang berbeda yaitu Gallirallus Philipensis dan Gallirallus Torquatus. Kedua jenis burung weris memiliki karakter kunci yang berbeda dapat dilihat dari
\end{abstract}

*Alumni Fakultas Peternakan Unsrat

*Jurusan Produksi Peternakan penampilan luar atau eksterior, yaitu perbedaannya warna dan corak bulu.

Kata kunci: Burung weris, Warna, corak bulu

\section{ABSTRACT}

STUDY ON FEATHER PATTERN AND COLORS OF "WERIS" BIRDS IN CITY OF KOTAMOBAGU. Mandar bird (Gallirallus) which in local language known as Weris (Minahasa), and Boruit (Kotamobagu) is a bird in the family Rallidae, are a family of birds that have small to medium body size. General habitat of this bird species is swamp, near a river or lake. Weris birds generally breed in densely vegetated areas According Rusila (1994). Identify an issue in the study is the identification of colors and feather patterns, two species weris birds that exist in Kotamobagus (North Sulawesi). The purpose of this study was to obtain date on the diversity of colors and patterns that exist in weris birds of Kotamobagu,Bolaang Mongondow, North Sulawesi. The expected benefits of this research is to provide information on the identification of plumage color and pattern weris birds, useful breeding process.

Weris birds in Indonesia consists of several types, based on the results of research conducted in Kotamobagu Bolaang Mongondow North Sulawesi weris got 2 different types of birds that Gallirallus Philipensis and Gallirallus torquatus. Both types of weris birds have different key characters can be seen from the 
outside or exterior appearance, that is the difference of colors and patterns.

Key words : Weris Birds, Color, and Patterns

\section{PENDAHULUAN}

Burung mandar atau dalam bahasa lokal (Minahasa) dikenal dengan burung weris sedangkan di Kotamobagu dan Bolmong dikenal sebagai burung Boruit merupakan jenis burung yang saat ini di duga mengalami penurunan jumlah populasi disebabkan perburuan yang sering dilakukan untuk konsumsi sebagai pemenuhan kebutuhan protein hewani, dibuktikan sulitnya memperoleh daging burung weris di pasar-pasar tradisional maupun restoran, yang dulunya menjual daging burung weris dan makanan olahan daging burung weris. Ukuran tubuh burung weris lebih kecil dibandingkan dengan ayam, namun daging burung weris sangat diminati oleh masyarakat di Minahasa, Kotamobagu dan Bolmong walaupun harga daging burung weris relatif mahal. Hal inilah yang diduga menyebabkan terjadinya penurunan populasi burung weris di Sulawesi Utara. Dari beberapa jenis burung weris yang ada di Sulawesi Utara, saat ini hanya ditemukan dua jenis yaitu Galliralus philippensis dan Galliralus torquatus (Lambey 2013). Kegiatan penangkaran merupakan salah satu cara yang dapat dilakukan untuk mencegah kepunahan dan diharapkan dapat meningkatkan populasi berbagai satwa khususnya burung weris yang ada di Sulawesi Utara. Salah satu cara yang harus dilakukan dalam penangkaran burung weris yaitu terlebih dahulu dilakukan indetifikasi warna dan corak buluh burung weris, hal ini dilakukan untuk melihat keragaman dan karakteristik genetik yang diharapkan dapat bermanfaat untuk pelestarian.

Berdasarkan latar belakang di atas didapati permasalahan bahwa faktor yang mempengaruhi penurunan populasi burung weris atau boruit disebabkan karna pemburuan yang sangat tinggi oleh masyarakat Sulawesi utara lebih khusus masyarakat Kotamobagu.

\section{MATERI DAN METODE PENELITIAN}

Penelitian ini dilakukan di Kotamobagu, Kabupaten Bolaang Mongondow Provinsi Sulawesi 
Utara dan lama penelitian adalah 43 hari dengan mengunakan 20 sampel burung weris dari 2 spesis. Materi penelitian yang di gunakan adalah Burung Weris yang berada di Kotakobagu Kabupaten Bolaang Mongondow Provinsi Sulawesi utara. Alat yang di gunakan :Pukat, Kandang pengumpul, Kamera, Alat Tulis Menulis, Timbangan, GPS.

Penelitian ini mengunakan metode survey, untuk mengetahui keberadaan burung weris di lokasi, kemudian dilakukan pengambilan sampel dengan dua cara yaitu mengunakan pukat untuk daerah persawaan dan mengunakan dodeso (jerat) untuk daerah perkebunan. Hasil tangkapan ditandai dengan menggunakan pita selanjutnya dilakukan indentifikasi secara visual dan dibantu dengan menggunakan kamera digital, bagian paruh, kepala, dada, sayap, ekor, shank, berdasarkan pendapat Coastes dan Bishop (2000).Parameter penelitian ini adalah mengamati dan mengidentifikasi warna dan corak bulu pada burung weris yang meliputi : habitat, warna bulu leher, warna bulu dada, warna bulu sayap, warna bulu ekor, warna alis mata, warna iris mata, warna paruh, warna shank, bentuk kaki, dan bentuk paruh.

Data yang diperoleh dianalisis dan disajikan secara deskriptif yaitu menguraikan dan menjelaskan tentang gambaran-gambaran umum dari hasil pengamatan secara langsung di lapangan.

\section{HASIL DAN PEMBAHASAN}

Warna Bulu Dada, Bulu Leher, Bulu Sayap, Bulu Ekor, Warna Paruh, Warna Iris Mata, Warna Shank Gallirallus philippensis, Gallirallus Torquatus

Hasil penelitian menunjukan bahwa warna bulu sayap burung weris Gallirallus Philippensis R1 sampai R10 memiliki kesamaan yaitu sayap primer bagian bulu terluar berwarna hitam kecoklatan dan memiliki empat garis putih bercampur dengan coklat sedangkan bagian dalam berwarna coklat dan memiliki lima garis hitam. Untuk bulu sekunder berwarna coklat dan memiliki lima garis hitam sampai R10 dengan berat yang berfariasi yaitu 169,1g, 144,2g. 254,7g, 169,9g, $136,6 \mathrm{~g}, \quad 159,4 \mathrm{~g}, \quad 138,1 \mathrm{~g} . \quad 152,8 \mathrm{~g}$, 163,4g, tidak memiliki perbedaan tetapi memiliki kesamaan dimana burung ini memiliki warna hitam 
bercorak putih (Gambar 2). Hasil penelitian di lapangan menunjukan bahwa warna dan corak yang terdapat pada bulu leher burung weris ini yaitu abu-abu pada pangkal leher bagian dalam, coklat muda terdapat pada leher bagian luar, dan dilengkapi dengan warna kuning muda yang melingkar pada bagian leher.

Hasil penelitian di lapangan menunjukan warna dan corak yang terdapat pada bulu ekor Gallirallus philippensis hitam corak putih pada pangkal ekor, dan pada ujung ekor berwarna coklat muda (Gambar 3).

Hasil penelitian di lapangan menunjukan bahwa bulu alis mata R1 sampai R10 berwarna putihri pangkjal paruh atas sampai pada bagian leher teratas (Gambar 4). Hasil penelitian di lapangan menunjukan bahwa warna paruh burung weris Gallirallus philippensis yaitu pada ujung paruh terdapat warna coklat, sedangkan di pangkal paruh berwarna merah mudah.

Penelitian di lapangan menunjukan bahwa burung R1 sampai R10 tidak ada perbedaan warna paruh. Burung R1 sampai R10 memiliki bentuk paruh yang panjang dan meruncing kedepan serta kokoh. Cere terdapat pada paruh bagian atas yang berfungsi seperti hidung. Paruh ini digunakan untuk mengambil makanan seperti serangga, biji-bijian, cacing yang ada dalam lumpur dan memecahkan cangkang crustacea untuk diambil isinya. R1-R10 memiliki bentuk paruh yang sama sehingga jenis makanan yang mereka peroleh sama (Gambar 4).

Penelitian di lapangan menunjukan iris mata yang terdapat pada burung ini tidak berbeda dari R1 sampai R10 dimana lingkaran merah terdapat pada bagian luar (Gambar 4). Warna iris mata diduga bisa menentukan umur burung weris. Warna iris mata Gallirallus philippensis akan berubah secara bertahap dari warna hitam kemudian menjadi coklat muda, selanjutnya berubah menjadi coklat tua dan akhirnya menjadi warna merah (Lambey 2013). Diduga R1 sampai R10 memiliki umur relatif sama, karena

R1,R2,R3,R4,R5,R6,R7,R8,R9 dan R10 memiliki warna iris mata yang sama yaitu merah.

Penelitian di lapangan menunjukan bahwa warna yang 
terdapat pada shank burung weris Gallirallus philippensis ini memiliki perbedaan dengan ketingian lokasi yang berfariasi diantaranya R1 warna shank adalah abu-abu muda sampai abu-abu tua dengan berat badan 161,4g, dengan ketingian lokasi 291 m. R2 memiliki warna shank coklat tua dengan berat badan 169,1g. Memiliki ketingian sama dengan R1, R3 memiliki warna coklat muda dengan berat badan 144,2 gram ketingian lokasi 291m. R4 memiliki warna coklat muda dengan berat badan $254,7 \mathrm{~g}$, ketinggian $235 \mathrm{~m}$. R5 warna shank coklat muda dengan berat badan 169.9 gram, memiliki ketinggian $235 \mathrm{~m}$. Warna shank R6 yaitu coklat muda dengan berat badan 136,6g, dengan ketingian 235m. R7 berwarna coklat muda dengan berat $159.4 \mathrm{~g}$, dengan ketinggian $235 \mathrm{~m}$. Warna shank R8 coklat tua dengan berat badan $134 \mathrm{~g}$. R9 warna coklat muda dengan berat badan $152 \mathrm{~g}$, dengan ketingian lokasi 291m. warna shank yang terdapat pada R10 yaitu coklat tua dengan berat badan $163.4 \mathrm{~g}$, dengan ketingian 235m (Gambar 5). Menurut Pough et al. (2005) menyatakan bahwa bentuk paruh dan kaki tiap burung berbeda disesuaikan dengan kebiasaan makan dan kemampuan lokomotif. Menurut McLelland dan King (1975), sebagian besar burung ditemukan digit I sampai IV (dengan jumlah tulang jari dua, tiga, empat dan lima). Jari pertama secara tepat berada paling belakang. Posisi dari jari-jari dapat digunakan untuk kepentingan taksonomi yang berkaitan dengan posisi burung saat bertengger atau pun tidak bertengger (Gambar 6).

Hasil penelitian di lapangan menunjukan burung weris (Gallirallus torquatus) memiliki warna sayap dari R1 sampai R10 tidak memiliki perbedaan yaitu sayap primer memiliki warna coklat tua dengan mempunyai enam garisan putih yang terdapat di unjung sayap terluar, bulu sayap sekundar memiliki warna coklat tua. walaupun dengan berat badan yang bervariasi maupun dengan ketingian lokasi penangkapan yang berbeda. Hickman et al. (2007) menyatakan bahwa sayap pada burung memiliki ukuran dan bentuk yang bervariasi karena perbedaan perkembangan dan disesuaikan dengan habitat (Gambar 7). 
Hasil penelitian di lapangan menunjukan bahwa warna bulu leher pada burung weris Gallirallus torquatus dari R1 sampai R10 adalaha hitam bercorak putih dari bagian bulu leher terdalam sampai bagian bulu leher terluar Gambar 8 .

Hasil penelitian di lapangan menunjukan bahwa warna bulu dada burung weris Gallirallus torquatus R1 sampai R10, tidak memiliki perbedaan dimana burung ini berwrna hitam bercorak putih. Gambar 8.

Hasil penelitian menunjukan warna dan corak bulu ekeor yang terdapat pada Gallirallus torquatus adalah berwarna coklat, hitam dan corak putih dari unjung ekor sampai pada pangkal ekor (Gambar 9).

\section{Warna Alis Mata, Warna Iris Mata, Dan Warna Paruh Pada Weris (Gallirallus torquatus).}

Penelitian di lapangan menunjukan warna garis putih dari R1 sampai R10 pada burung Gallirallus torquatus yang terletak di bawa mata.Gambar 10.

Hasil penelitian di lapangan menunjukan bahwa warna iris mata pada burung ini tidak memiliki perbedaan yaitu merah terdapat bagian luar, yang di teliti dari lingkara mata bagian terluar dari R1 sampai R10. Gambar 10.

Warna paru yang terdapat pada burung ini adalah berwarna hitam mulai dari pangkal paruh sampai ujung paruh. Burung R1 sampai R10 memiliki bentuk paruh yang panjang dan meruncing kedepan serta kokoh. Cere terdapat pada paruh bagian atas yang berfungsi seperti hidung. Paruh ini digunakan untuk mengambil makanan seperti serangga, biji-bijian, cacing yang ada dalam lumpur dan memecahkan cangkang crustacea untuk diambil isinya. R1-R0 memiliki bentuk paruh yang sama sehingga jenis makanan yang mereka peroleh sama. Gambar 10.

Warna shank yang terdapat pada burung ini dengan ketingiaan $235 \mathrm{~m}$. adalah coklat dari R1 sampai R 10 tidak memiliki perbedaan dengan berat berat yang berfariassi dimana R1 memili berat 194.2 gram, R2 bobot badan 180.1 garam, R3 bobot badan 168.1 gram, R4 bobot badan 180.5 gram, R5 bobot badan 190.7 gram, R6 bobot badan 190.1 gram, R7 bobot badan 189.6 gram, R8 bobot badan 194.5 garam, R9 190.1 
gram, R10 bobot badan 189.1 gram.

adalah syndactyl. Gambar 11.

Bentuk shank pada burung ini
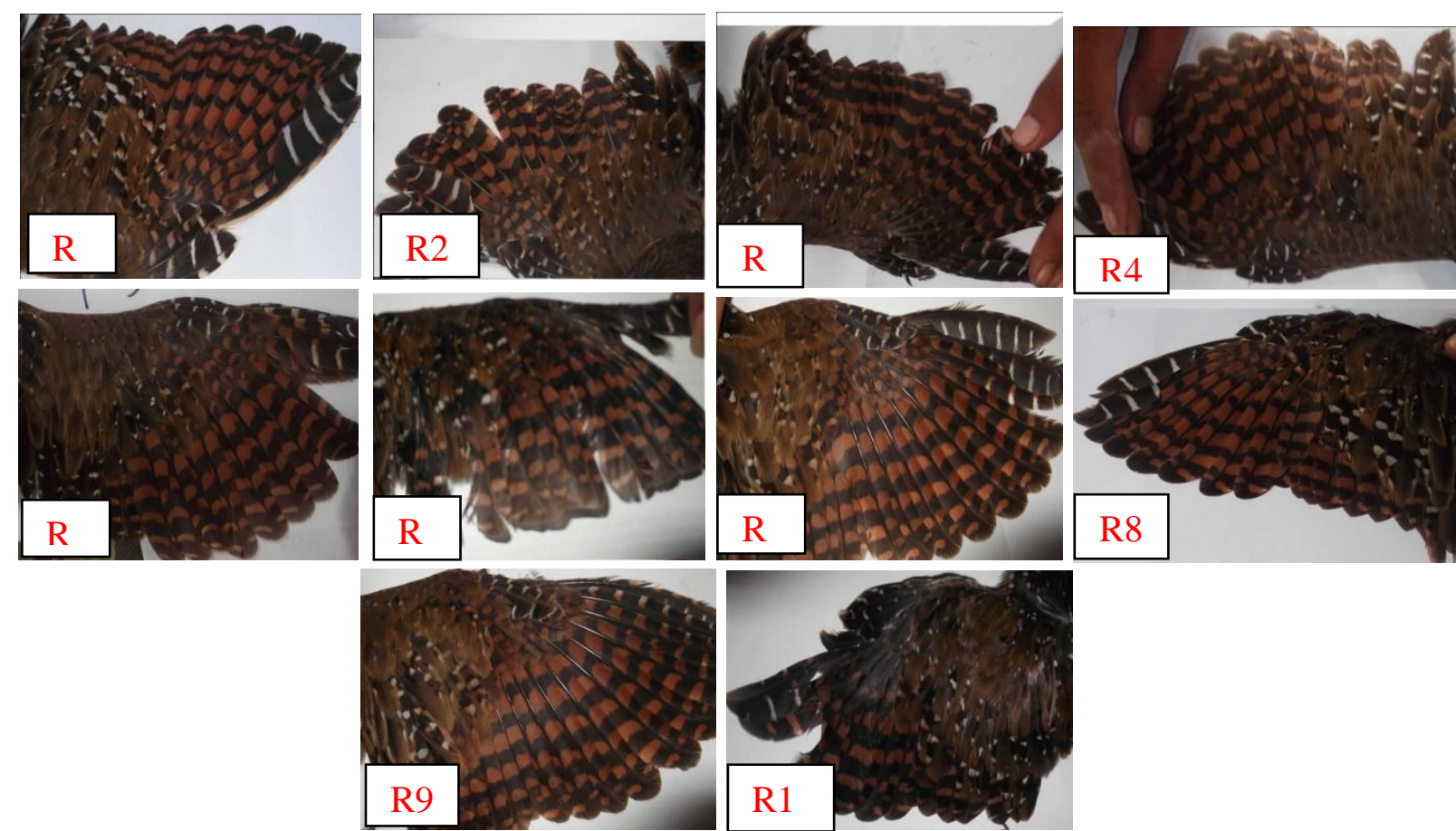

Gambar 1 Warna dan corak bulu sayap pada Gallirallus philipensis 

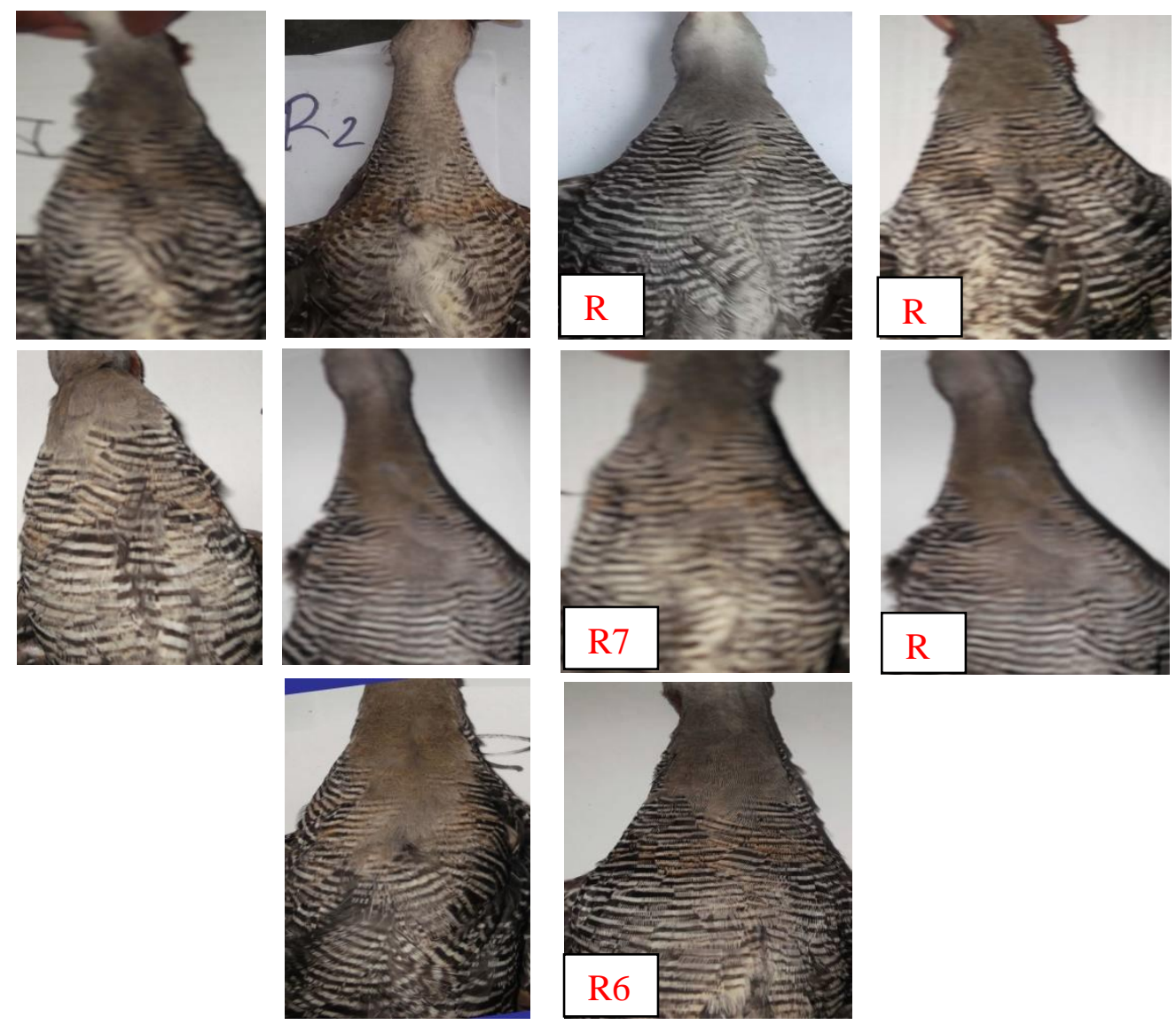

Gambar 2 Bulu dada dan leher pada Gallirallus philipensis 


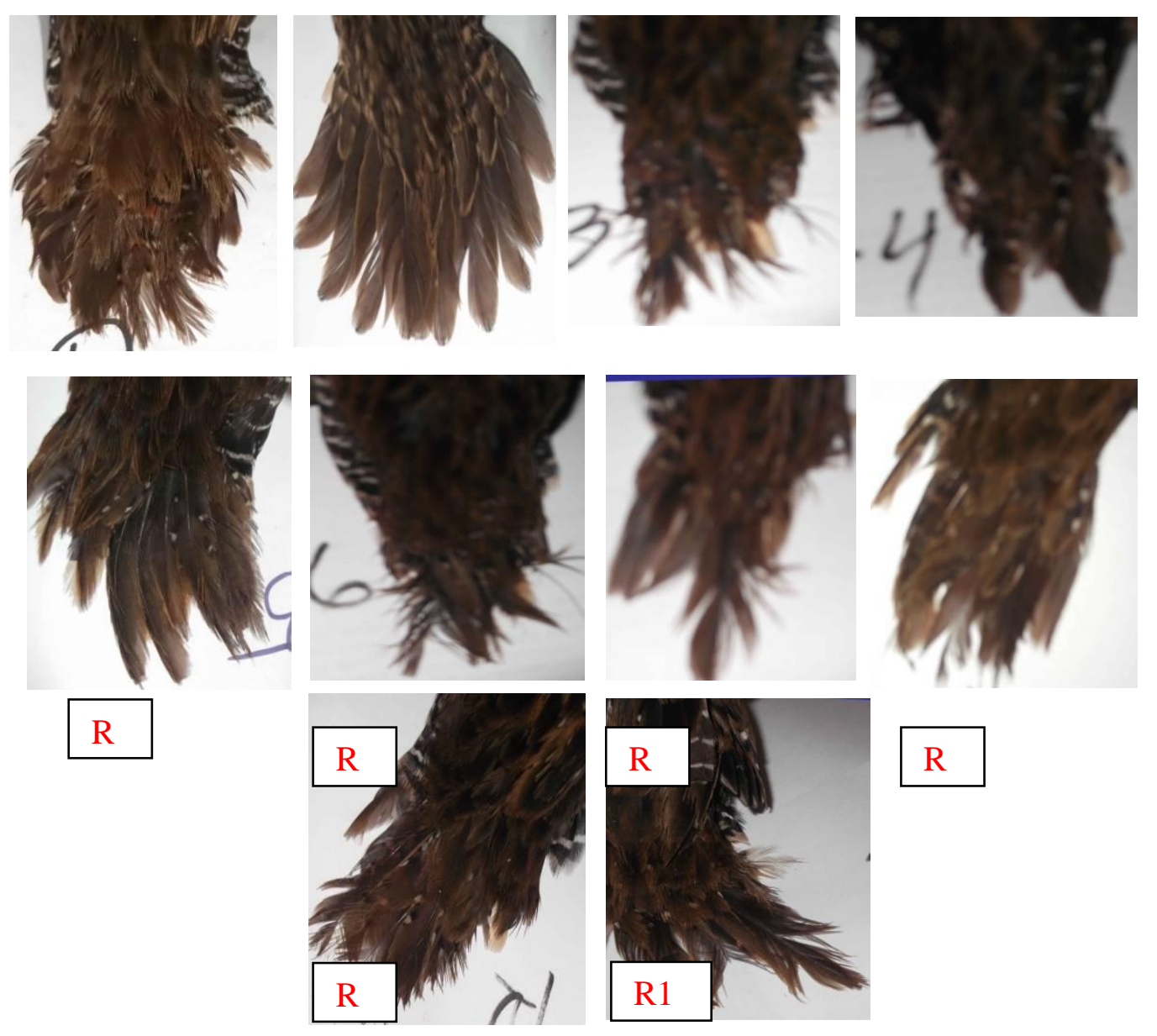

Gambar 3 Bulu ekor pada Gallirallus philipensis.

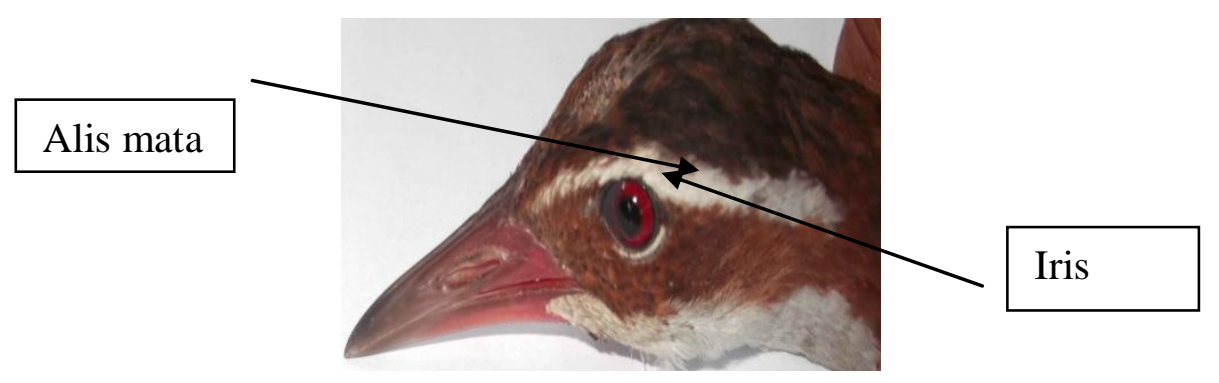


Gambar 4a. Warna alis mata dan iris mata Gallirallus pilipensis
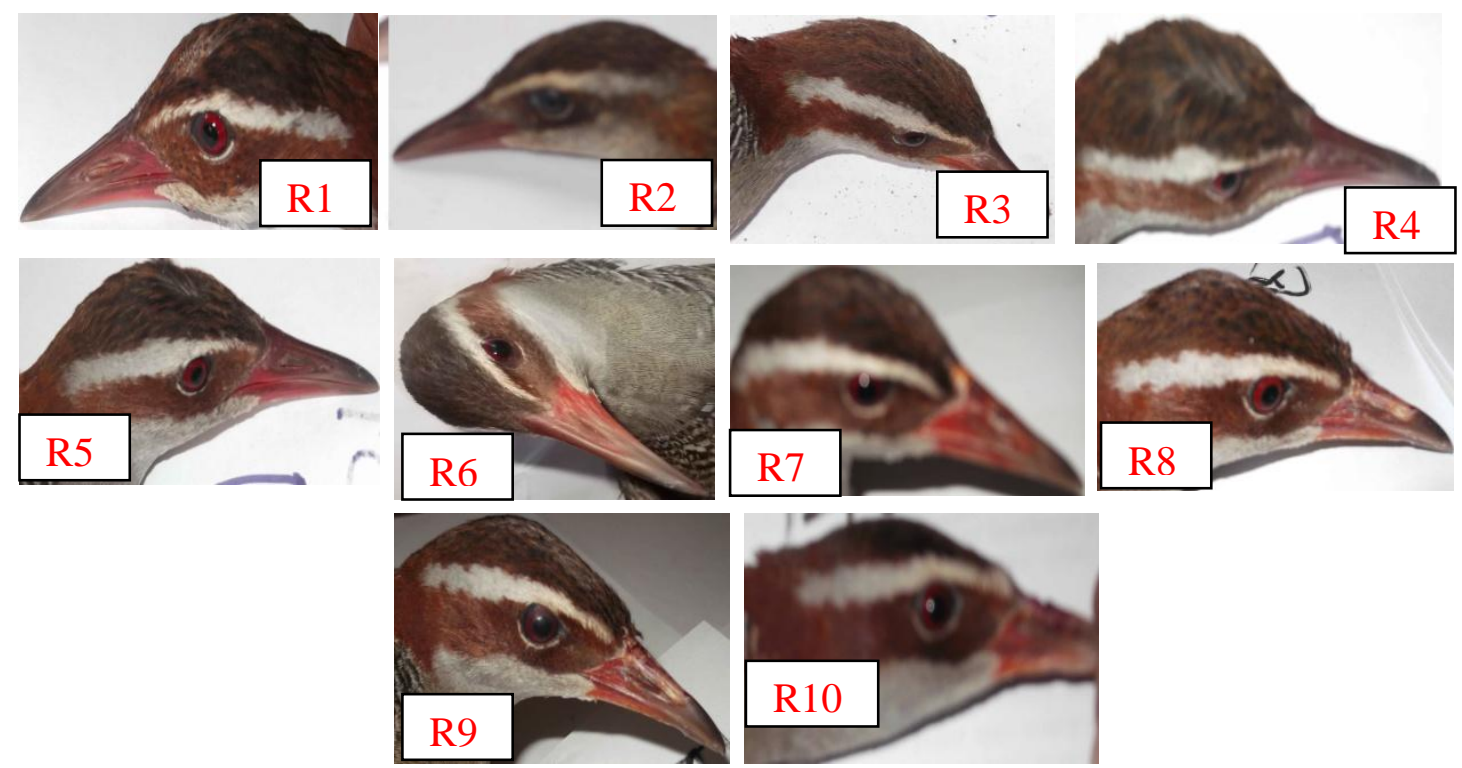

Gambar 4b. warna paruh pada Gallirallus pilipensis
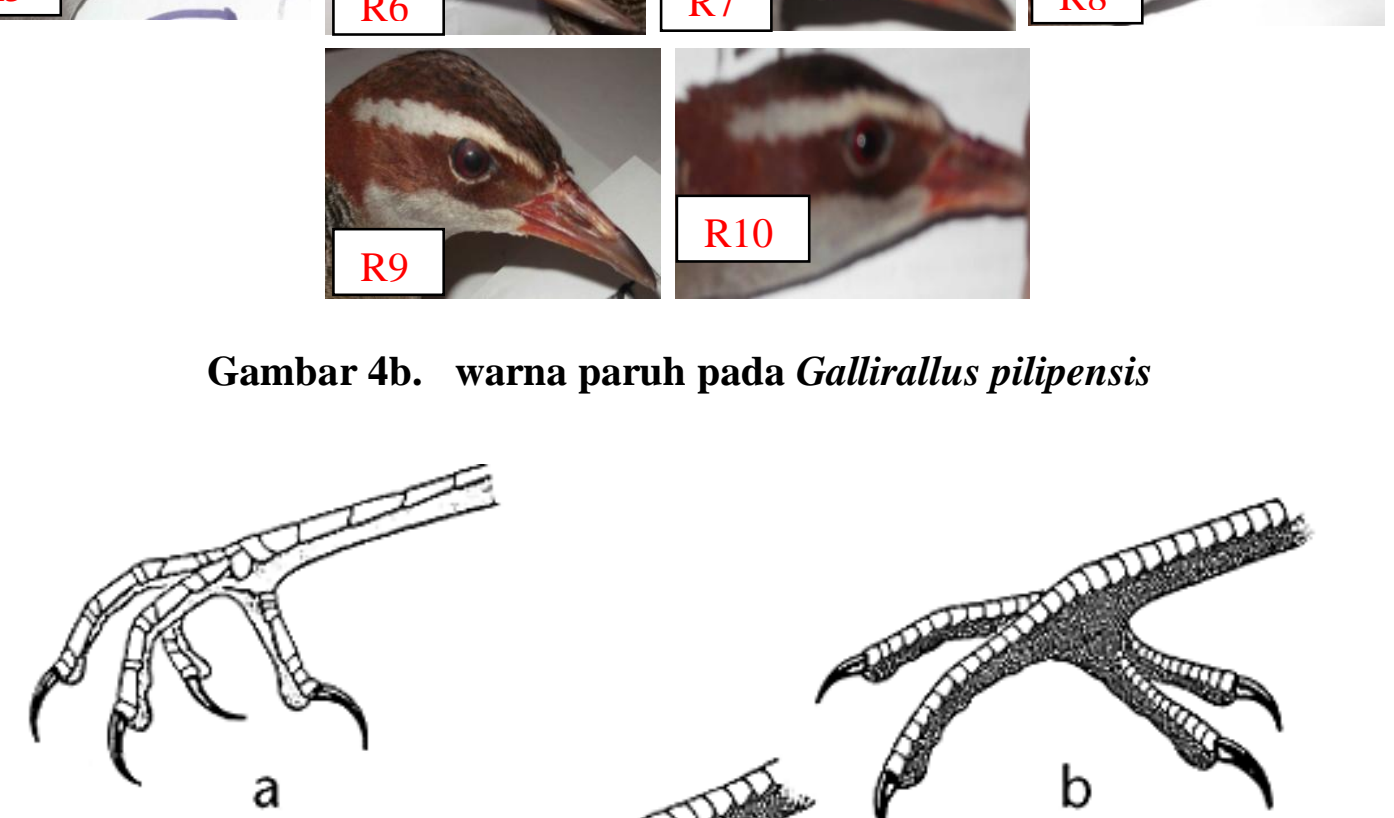

a

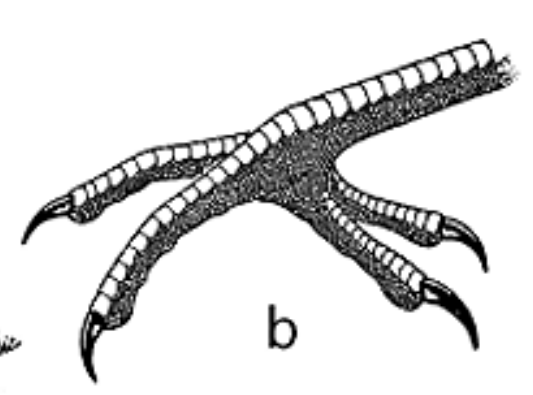

C
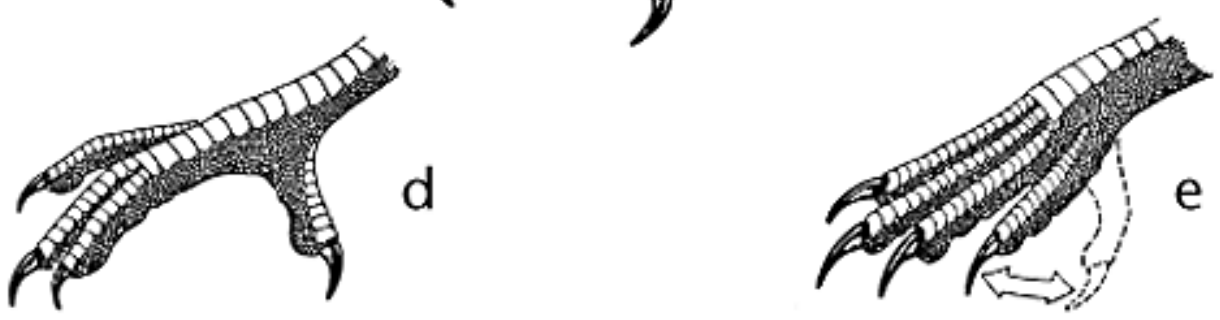

Gambar 5. Keterangan pada gambar $6: \mathrm{a}=$ anisodactyl, $\mathrm{b}=$ zygodactyl, $\mathrm{c}$ $=$ heterodactyl, $\mathrm{d}=$ syndactyl, \& e =pamprodactyl Sumber: Proctor dan Lynch (1993) 

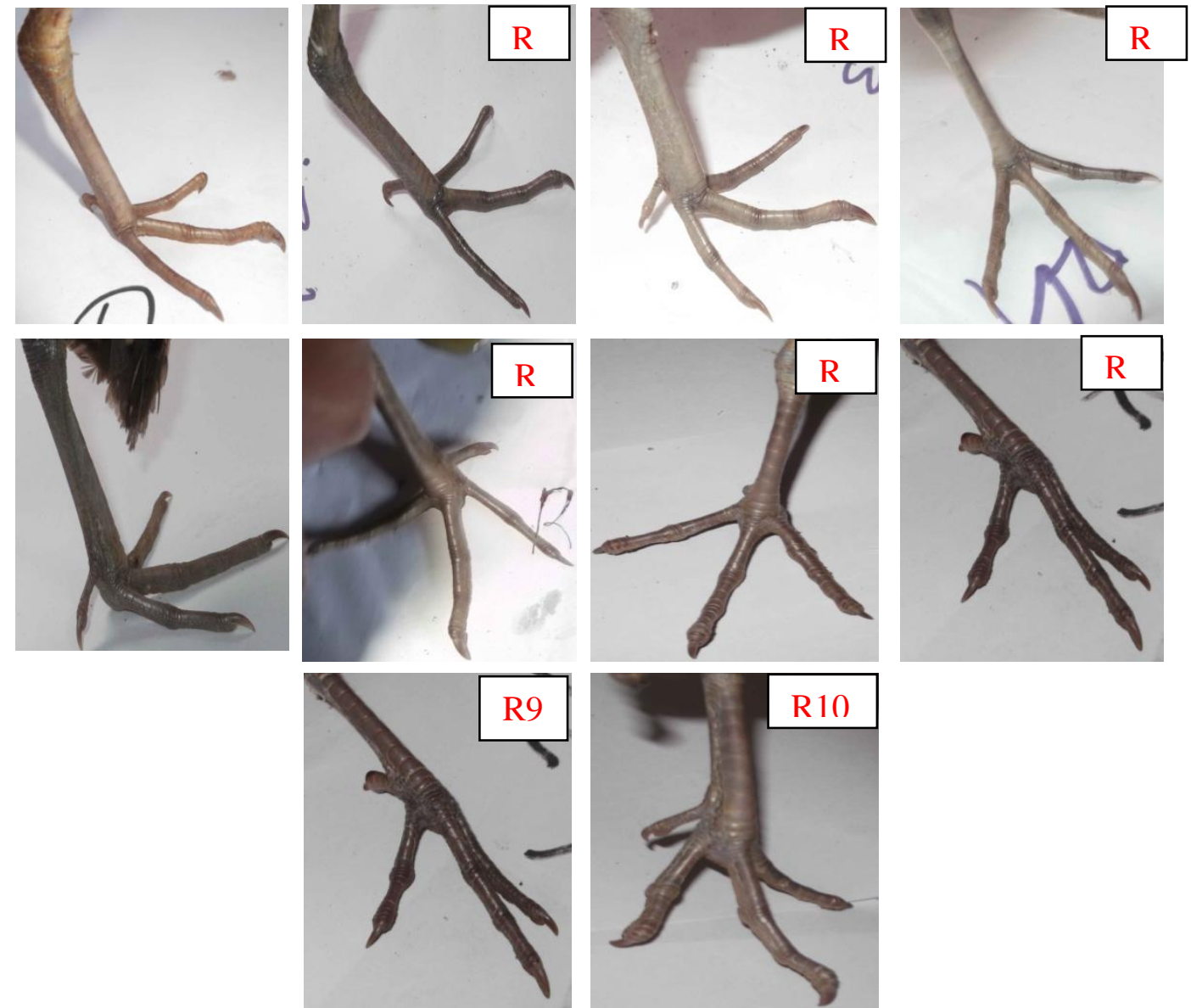

Gambar 6 . Warna shank pada Gallirallus philipensis

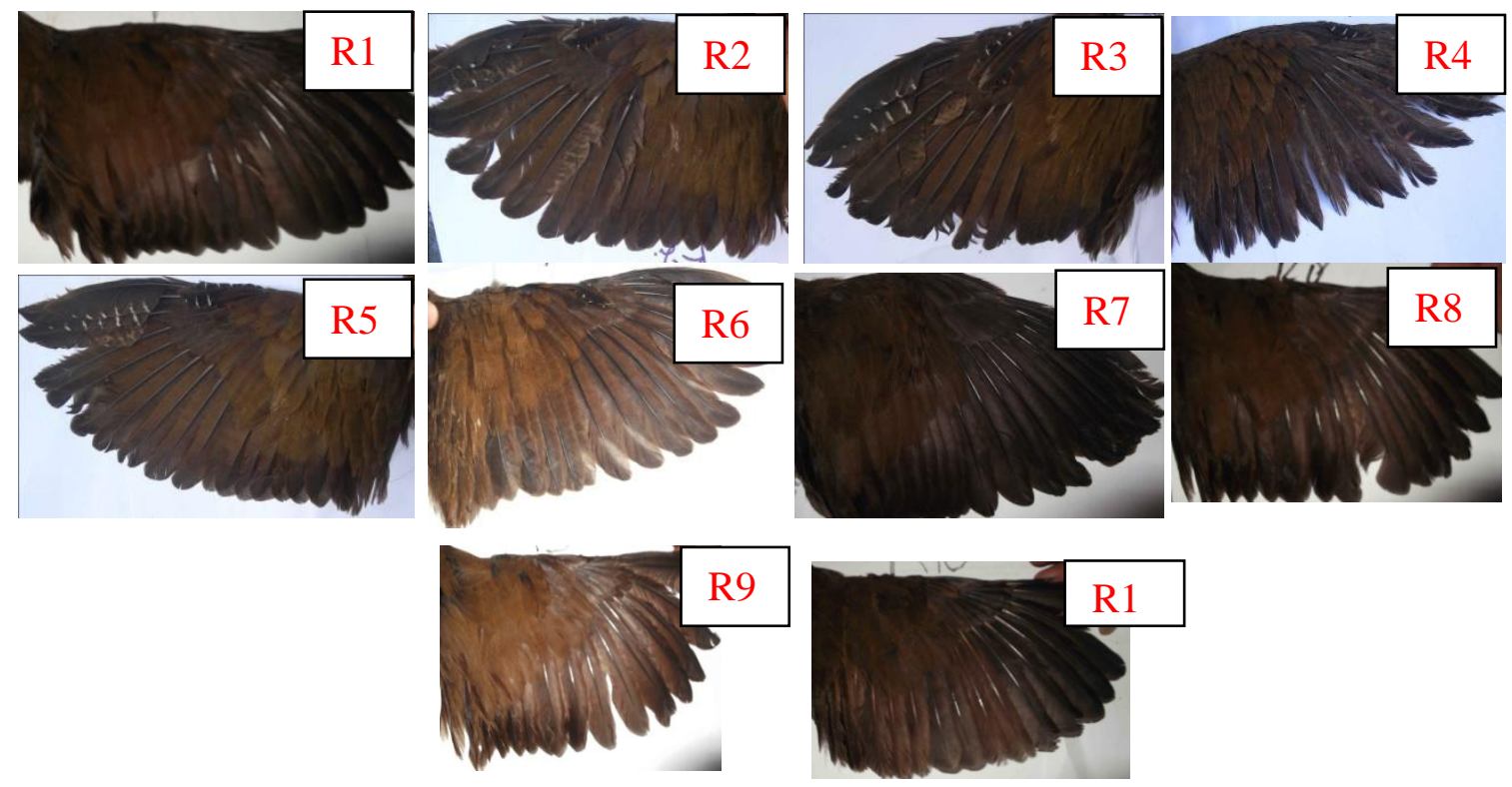

Gambar 7 Warna bulu sayap Gallirallus torquatus 

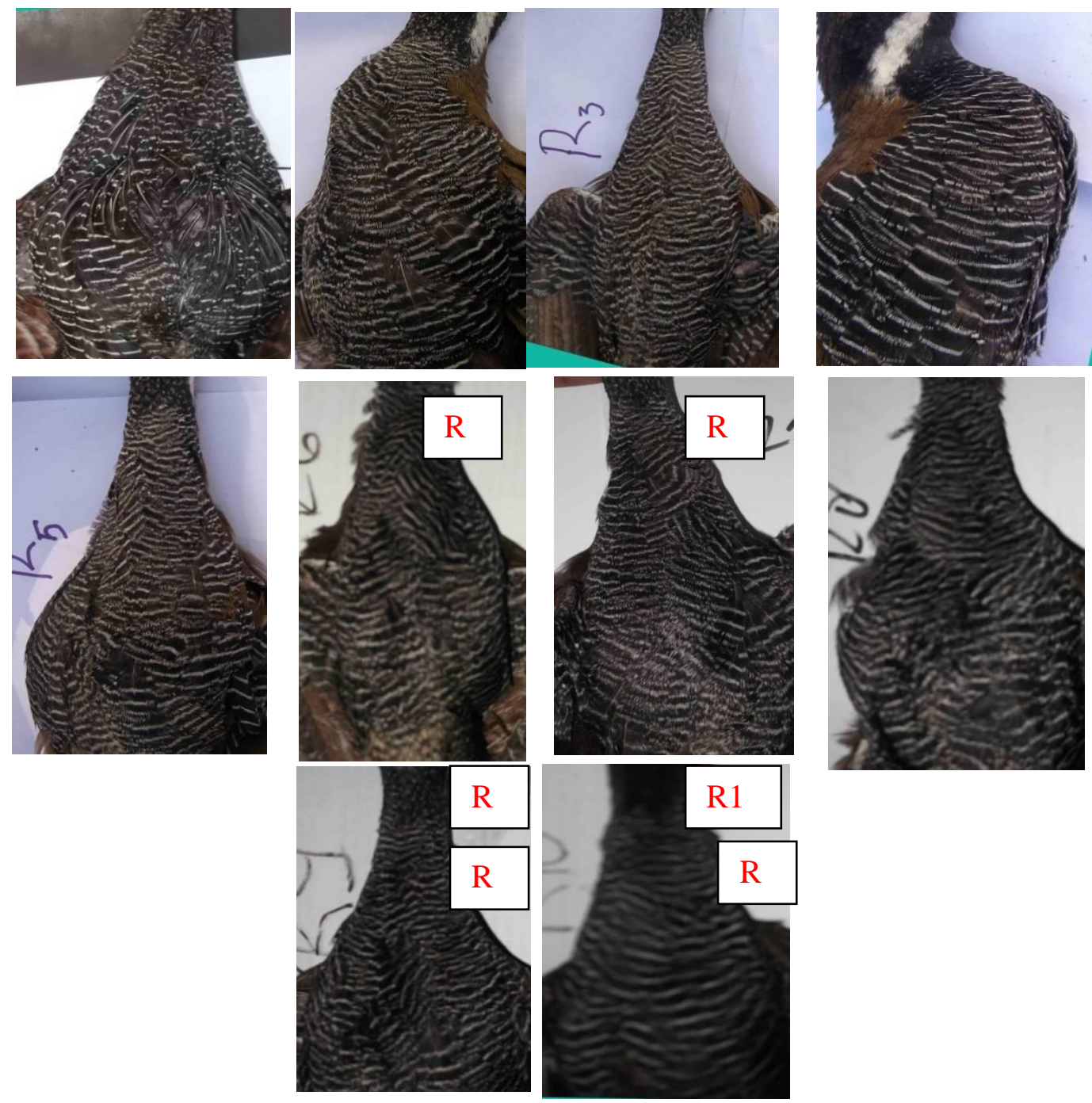

Gambar 8. Warna dan corak bulu dada, dan leher pada Gallirallus torquatus 


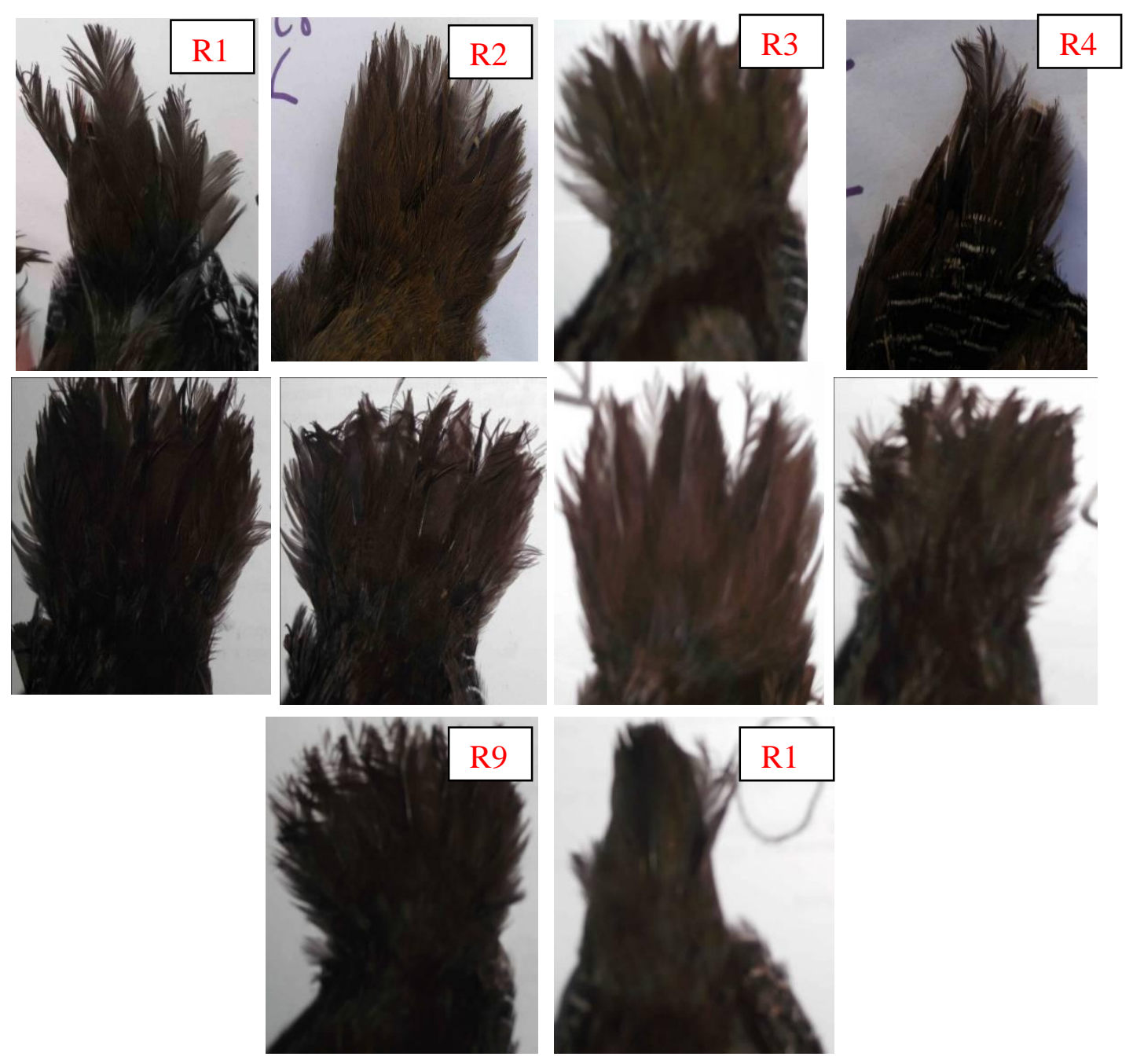

Gambar 9. Warna bulu ekor Gallirallus torquatus

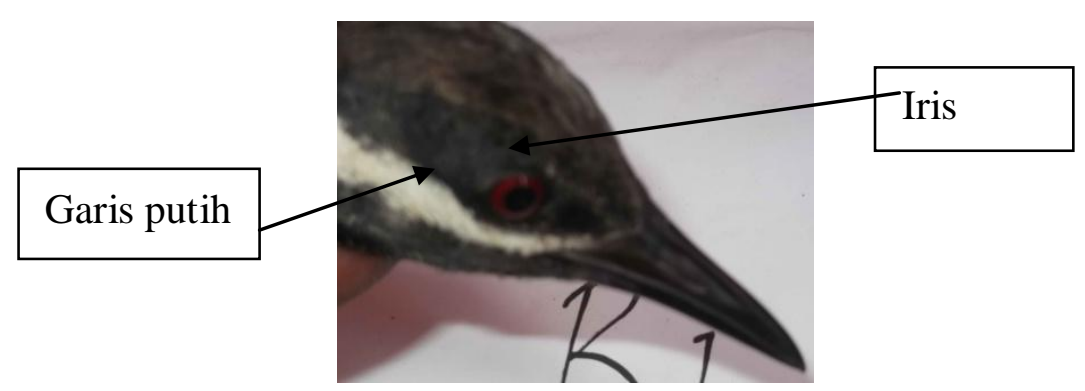

Gambar 10. Warna garis dan iris mata Gallirallus torquatus 


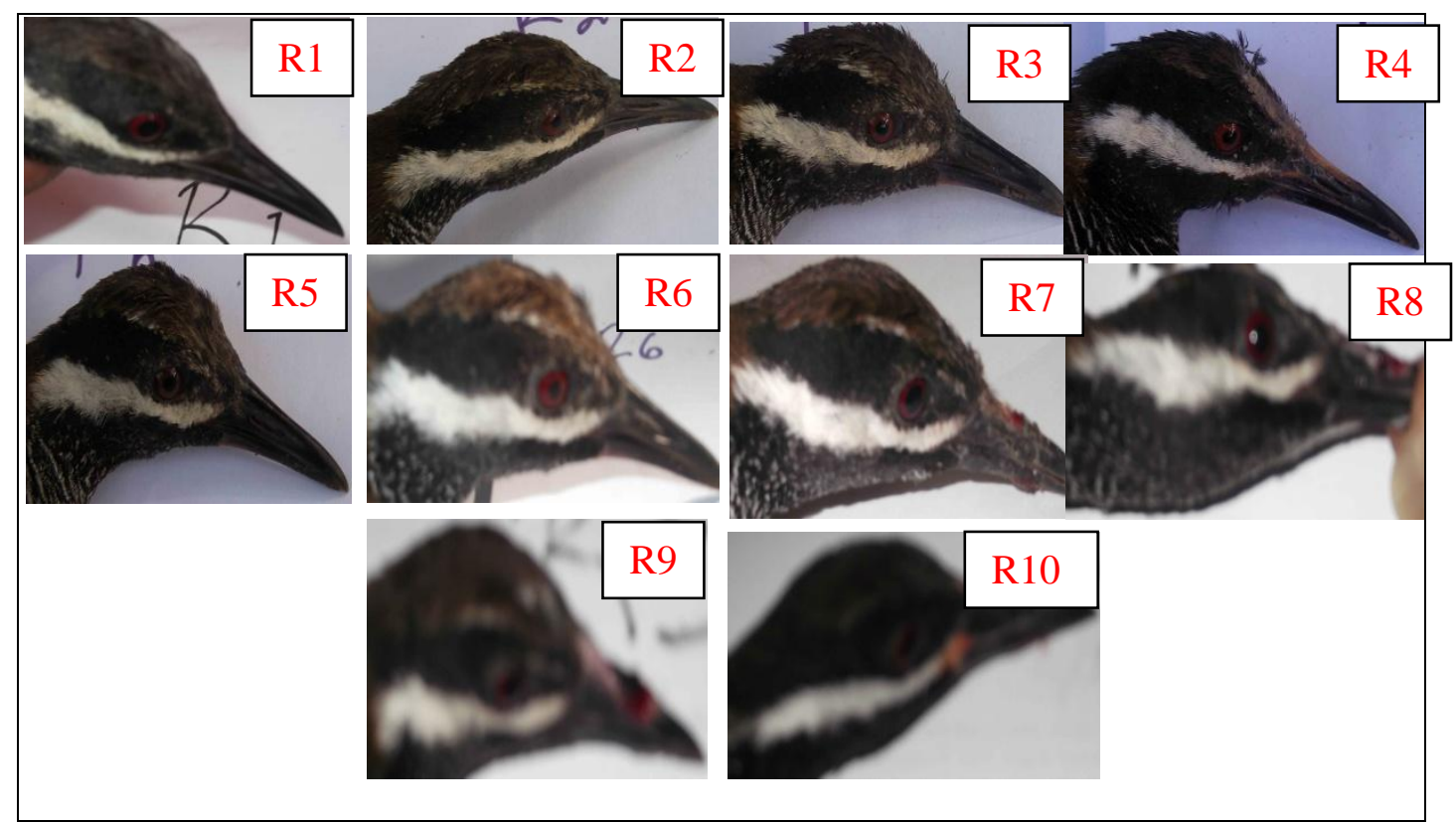

Gambar 11. Warna garis mata, warna iris mata dan warna paruh pada Gallirallus torquatus 


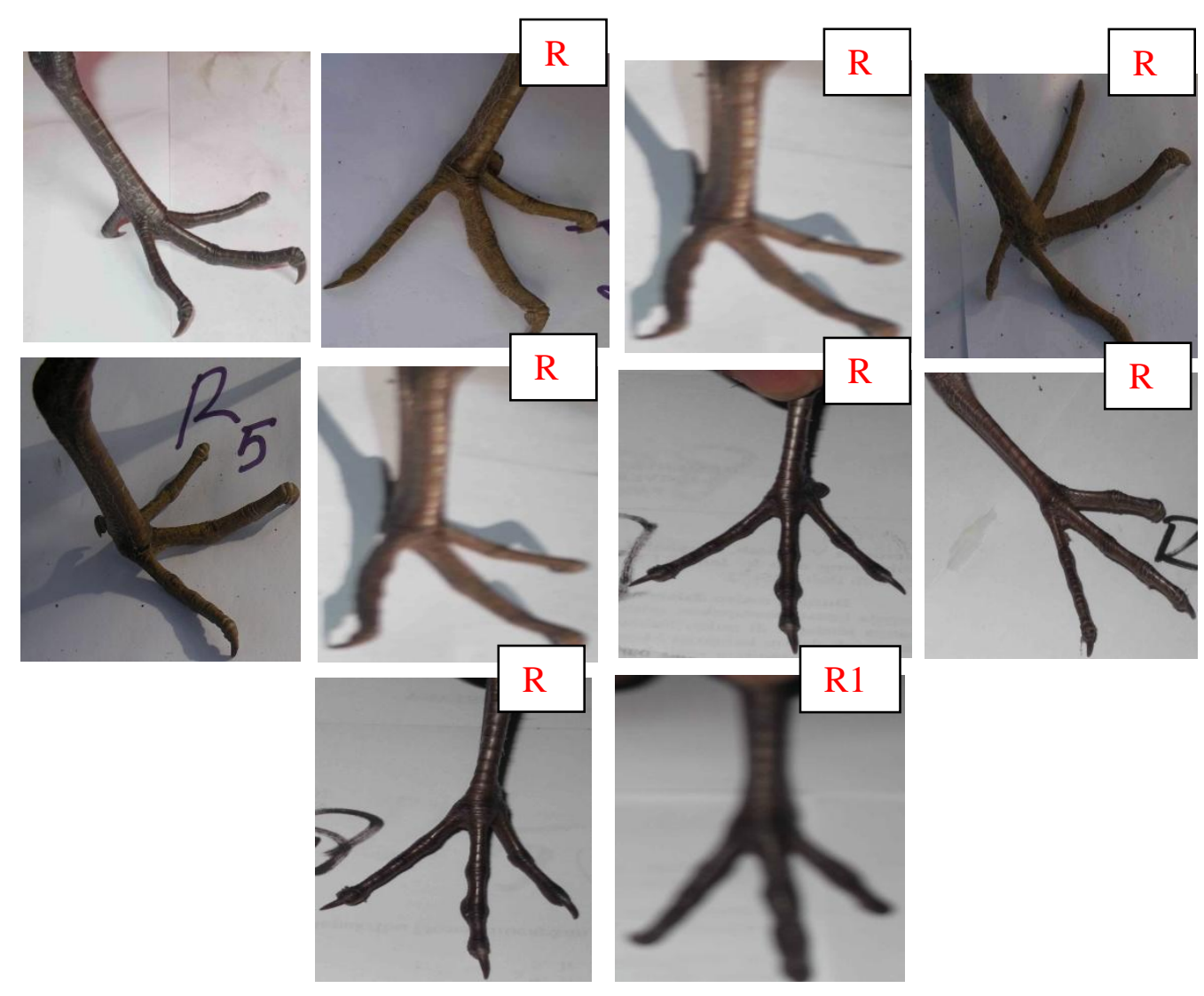

Gambar 12. Warna shank Gallirallus torquatus 


\section{KESIMPULAN}

Dari hasil penelitian disimpulkan bahwa burung weris di Kotamobagu terdapat 2 spesis yaitu

1 Kedua jenis burung weris memiliki karakter kunci yang berbeda dapat dilihat dari penampilan luar atau eksterior, yaitu Galliralus phlipensis dan Galirallus torquatus memiliki karakter kunci yang berbeda yaitu pada bagian atas mata Galliralus phlipensis terdapat warna putih dan pada bagian bawah mata Galliralus turquatus nterdapat garisan warna putih..

2 Gallirallus philipensis dan Gallirallus torquatus adalah burung monomrfik.

\section{DAFTAR PUSAKA}

Coastes BJ, Bishop KD. 2000. Panduan Lapangan BUrung-burung di Kawasan Wallacea. (Sulawesi, Maluku, dan Nusa Tenggara). Bird Life International.

Hickman, C.P., L.S. Roberts, S.L. Keen, A. Larson dan D.J. Eisenhour. 2007. Animal Diversity. Mc Graw-Hill, New York.
Lambey L. J. Noor R. R. Manalu W. Duryadi D. 2013. Karakteristik Morfologi Perbedaan jenis Kelamin, dan Pendugaan Umur Burung Weris (Gallillarus phlippensis) di Minahasa, Sulawesi Utara. Veteriner 14:228-238.

McLelland, J. dan A.S. King. 1975. Outlines of Avian Anatomy. Bailliere Tindall,London.

Rusila Noor Y. 1994. Pengetahuan Tentang Burung Air Khususnya Burung Air Bermigrasi (Migratory Waterbirds). Di Indonesia Makalah disajikan pada Watland Conservation Assement and Manogement Trainng Course III. Bogor 03 September 1994. Pusdiklat Pegawai \& SDM kehutanan. Bogor. PHPA/AWB.

Pough, F.H., C.M. Janis dan J.B. Heiser. 2005. Vertebrate Life. Seventh Edition. Pearson Education Inc. New Jersey 